\title{
Triple-negative breast cancers express receptors for luteinizing hormone-releasing hormone (LHRH) and respond to LHRH antagonist Cetrorelix with growth inhibition
}

\author{
STEFAN BUCHHOLZ ${ }^{1,2,4}$, STEPHAN SEITZ ${ }^{1,2,4}$, ANDREW V. SCHALLY $Y^{1-3}$, JÖRG B. ENGEL ${ }^{5}$, \\ FERENC G. RICK ${ }^{1,2}$, LUCA SZALONTAY ${ }^{1,2}$, FLORIAN HOHLA ${ }^{1,2,6}$, AWTAR KRISHAN ${ }^{2}$, ANDREA PAPADIA ${ }^{7}$, \\ TIMO GAISER $^{8}$, GERO BROCKHOFF ${ }^{4}$, OLAF ORTMANN ${ }^{4}$, KLAUS DIEDRICH ${ }^{9}$ and FRANK KÖSTER ${ }^{9}$ \\ ${ }^{1}$ The Endocrine, Polypeptide and Cancer Institute, Veterans Affairs Medical Center and South Florida VA Foundation \\ for Research and Education, 1201 NW 16th Street, Miami, FL 33125; ${ }^{2}$ Department of Pathology, ${ }^{3}$ Department of Medicine, \\ Division of Hematology/Oncology, Miller School of Medicine, University of Miami, 1611 NW 12th Avenue, Miami, \\ FL 33136, USA; ${ }^{4}$ Department of Gynecology and Obstetrics, University of Regensburg, Landshuter Str. 65 , \\ D-93053 Regensburg; ${ }^{5}$ Department of Gynecology and Obstetrics, Medical University of Würzburg, Josef-Schneider-Str. 4, \\ D-97080 Würzburg, Germany; ${ }^{6}$ Department of Internal Medicine, General Hospital Oberndorf, Teaching Hospital of the \\ Paracelsus Medical University of Salzburg, Paracelsusstr. 37, A-5110 Oberndorf, Austria; ${ }^{7}$ Department of Obstetrics \\ and Gynecology, UM/Sylvester Comprehensive Cancer Center, 1475 NW, 12th Avenue, Miami, FL 33136, USA; \\ ${ }^{8}$ Department of Neuropathology, Medical University of Heidelberg, Im Neuenheimer Feld 220/221, D-69120 Heidelberg; \\ ${ }^{9}$ Department of Gynecology and Obstetrics, University of Lübeck, Ratzeburger Allee 160, D-23538 Lübeck, Germany
}

Received March 16, 2009; Accepted May 22, 2009

DOI: 10.3892/ijo_00000391

\begin{abstract}
The aim of the present study was to evaluate the expression of receptors for luteinizing hormone-releasing hormone (LHRH) in human specimens of triple-negative breast cancers (TNBC). In addition, we used in vitro and in vivo models of TNBC to investigate if these receptors are suitable targets for the treatment with the LHRH antagonist Cetrorelix. Receptors for LHRH were expressed in all tumor samples and in the TNBC cell lines HCC1806 and HCC1937. The proliferation of both TNBC cell lines was significantly inhibited in vitro by $1 \mu \mathrm{M}$ Cetrorelix. Injections of $3 \mathrm{mg}$ Cetrorelix on day 1 and 21 resulted in a significant growth inhibition of HCC1806 tumors xenografted into nude mice. Tumors of mice treated with Cetrorelix expressed less mRNA for EGFR and HER3 receptors than untreated tumors. After treatment of cells with Cetrorelix a flow cytometric analysis of the cell cycle revealed a decrease in S-phase. Given the low toxicity and clinical availability of Cetrorelix, this peptide
\end{abstract}

Correspondence to: Dr Frank Köster, Department of Gynecology and Obstetrics, University of Lübeck, Ratzeburger Allee 160, D-23538 Lübeck, Germany

E-mail: frank.koester@uk-sh.de

Key words: triple-negative breast cancer, LHRH antagonist, LHRH receptor, xenografted mouse model, cell cycle analysis antagonist should be considered for phase II studies in patients with advanced TNBC.

\section{Introduction}

Breast cancer is a heterogeneous disease that encompasses several distinct biological and clinical entities. Presently, breast cancer patients are treated by different approaches according to various clinical parameters in conjunction with assessment of the status of estrogen and progesterone receptors, and the overexpression of HER2 receptors. Effective therapies have been developed for patients with hormone receptor-positive or HER2-positive disease, but at present chemotherapy is the only systemic therapy for patients with triple-negative breast cancers (TNBC).

The definition of TNBC applies to a group of tumors, which do not express receptors for estrogen or progesterone and which do not overexpress HER2 receptors. Tumors belonging to this subgroup are often of the basal-like subtype, i.e., they express genes characteristic of basal epithelial cells. However, not all TNBCs are basal cell-like tumors, thus these two terms are not used as synonyms. TNBCs account for $10-17 \%$ of all breast carcinomas $(1,2)$, show distinctive clinical features and tend to affect more frequently younger patients (3). TNBCs are more prevalent in AfricanAmerican women (4) and are clinically more aggressive than tumors that belong to other known molecular subgroups $(1,2,5,6)$. TNBCs are sensitive to chemotherapy $(1)$, but the prognosis of TNBC patients is poor. Thus, in patients with TNBC disease, the recurrence takes place earlier and most deaths occur in the first five years after diagnosis $(2,7)$. 
These findings point out the paramount importance of the development of novel therapies for TNBC.

Specific receptors for luteinizing hormone-releasing hormone (LHRH) have been so far detected on a variety of human cancer cells, such as breast, prostatic, ovarian, endometrial, colorectal and pancreatic cancers as well as melanomas and non-Hodgkin's lymphoma (8-17). The production of an LHRH-like peptide and/or the expression of mRNA for LHRH was also demonstrated in various human cancer cell lines $(8,14,18)$. These and other findings imply that locally produced LHRH could be involved in the growth of these tumors through an autocrine regulatory loop. This concept is supported by an inhibitory effect of LHRH agonists and LHRH antagonist Cetrorelix on human mammary, prostatic, ovarian and endometrial cancer cell lines in vitro through specific tumoral LHRH receptors under conditions which exclude effects through the pituitary and the gonads $(14,15,18-20)$. Particularly relevant could be the demonstration of the inhibitory effects of Cetrorelix on growth of MDAMB-231 and MCF-7 human breast cancer cells in vitro (21-25).

Targeted cytotoxic LHRH analogs also inhibit the growth of human mammary, prostatic, ovarian, endometrial, colorectal cancers as well as melanomas, non-Hodgkin's lymphomas and renal carcinomas xenografted into nude mice $(12,15,18,22,26)$.

These experimental results suggest a regulatory role for LHRH-like peptides on tumor growth $(14,18,21,27,28)$. Consequently LHRH antagonists like Cetrorelix could be considered for the development of new therapies for LHRH receptor positive cancers (17).

In the present study we investigated the expression of LHRH receptors on specimens and cell lines of human TNBC by Western blot analysis, RT-PCR and immunohistochemistry. The anti-tumor efficacy and the mechanism of action of the LHRH antagonist Cetrorelix were then evaluated in vitro and in vivo in models of two human TNBC cell lines.

\section{Materials and methods}

Human specimens and detection of LHRH receptors by immunohistochemistry. Tissues of 17 human TNBC specimens derived from primary tumors and metastases were fixed for 16-20 $\mathrm{h}$ in $4 \%$ neutral buffered formalin and then embedded in paraffin. All patients have been informed and given written consent for the use of their tumor material. The study was approved by the local ethics committee. Sections 2-4 $\mu \mathrm{m}$ thick from selected tissue blocks were cut, mounted on siliconized glass slides (Sigma, Deisenhofen, Germany) and dried at $60^{\circ} \mathrm{C}$ for $30 \mathrm{~min}$ and at $38^{\circ} \mathrm{C}$ overnight. The sections were deparaffinized by two incubations in a xylene bath for $5 \mathrm{~min}$, twice in acetone for $5 \mathrm{~min}$ and finally in distilled water for $5 \mathrm{~min}$. The sections were heat pre-treated in $10 \mathrm{mM}$ citrate buffer, $\mathrm{pH} 6.0$ in a steamer for $30 \mathrm{~min}$, followed by washing in distilled water. Endogenous peroxidase was blocked by incubation in a freshly prepared solution of $0.3 \%$ $\mathrm{H}_{2} \mathrm{O}_{2}$ in methanol for $20 \mathrm{~min}$ at room temperature followed by washing in distilled water for $5 \mathrm{~min}$. The following steps were performed in a Tecan-Immunostainer Genesis RSP 200 (Software: Gemini 3.40), according to the manufacturer's EnVision+-staining procedure (Dako, Hamburg, Germany): The slides were rinsed twice in PBS-buffer (PBS/0.05\%
Tween-20, pH 7.4) for 7 min and incubated with an antibody for LHRH receptors (clone A9E4, Novocastra, UK) for $4 \mathrm{~h}$ (1:10 dilution in antibody diluent, Dako). The reaction was stopped with $100 \mu 1$ PBS-buffer per slide. After washing in $1400 \mu 1$ PBS-buffer for $7 \mathrm{~min}$, the slides were incubated with $120 \mu 1$ EnVision HRP anti-mouse antibody (Dako) for $30 \mathrm{~min}$. After washing in $1400 \mu \mathrm{l}$ PBS-buffer for $7 \mathrm{~min}$, the staining reaction was performed with $120 \mu \mathrm{l} /$ slide of DAB solution (Dako; at 1:50 dilution in substrate buffer) for $10 \mathrm{~min}$. The reaction was stopped with $100 \mu 1$ PBS-buffer for $20 \mathrm{~min}$, followed by washing with $1400 \mu 1$ PBS-buffer for $7 \mathrm{~min}$. The slides were then washed three times for $2 \mathrm{~h}$ with PBS-buffer. Finally, the slides were rinsed in water, counterstained with Harris' hematoxylin and covered with a glass slides. The sections were examined by light microscopy and the expression of LHRH receptors was estimated on a four point scale as absent $(-)$, weak expression $(+)$, distinct expression $(++)$ and strong expression $(+++)$.

Peptide preparations. The LHRH antagonist Cetrorelix, [Ac-D-Nal(2)1,D-Phe(4Cl)2,D-Pal(3)3,D-Cit6,D-Ala10]LHRH, originally synthesized in our laboratory by solid-phase methods (11) was made by Aeterna-Zentaris (Frankfurt-onMain, Germany) as Cetrorelix acetate (D20761). For in vitro experiments, Cetrorelix acetate was dissolved in $0.1 \%$ DMSO and diluted in media. For in vivo experiments we used a depot formulation of Cetrorelix pamoate (D20762), also provided by Aeterna-Zentaris, containing Cetrorelix peptide-base and pamoic acid in a molar ratio of $2: 1$, respectively. For the injection, Cetrorelix pamoate was dissolved in distilled water at a final concentration of $15 \mathrm{mg} / \mathrm{ml}$ in $5 \%$ mannitol. Aliquots of this solution $(3 \mathrm{mg} / 0.2 \mathrm{ml})$ were injected subcutaneously (s.c.) into mice, providing an estimated daily release of about $100 \mu \mathrm{g}$ of Cetrorelix for at least 21 days.

Cell culture. HCC1806 and HCC1937 cell lines derived from patients with diagnosed TNBC were obtained from the American Type Culture Collection (Manassas, VA). Cells were cultured in DMEM supplemented with $10 \%$ fetal bovine serum (FBS) and penicillin/streptomycin (all Invitrogen, Karlsruhe, Germany) in a humidified atmosphere containing $5 \% \mathrm{CO}_{2} / 95 \%$ air at $37^{\circ} \mathrm{C}$.

Animals. Five- to six-week-old female athymic nude mice (Ncr nu/nu) were obtained from NCI (Bethesda, MD, USA). The animals were housed in sterile cages under laminar flow hoods in a temperature-controlled room with a 12-h light/12-h dark schedule and were fed autoclaved chow and water ad libitum.

Animal experiment. Tumors resulting 4 weeks after transplantation into donor animals were aseptically dissected and mechanically minced. Pieces of tumor tissue, about $3 \mathrm{~mm}^{3}$, were transplanted s.c. into the experimental animals using a trocar needle. Four weeks after transplantation, animals bearing HCC1806 tumors were divided into two groups with an average tumor volume of $\sim 70 \mathrm{~mm}^{3}$. The mice received the following treatment as two subcutaneous injections on days 1 and 21: Group 1: control, vehicle solution (7 mice); group 2: treatment group, $3 \mathrm{mg} /$ mouse depot preparation Cetrorelix 
pamoate $(7$ mice). The experiment was terminated on day 35 after the first treatment. Tumor volume (length $\mathrm{x}$ width $\mathrm{x}$ height $\mathrm{x} 0.5236$ ) and body weight were measured weekly. At the end of each experiment, mice were sacrificed under anesthesia, tumors were excised and weighed, and further necropsy was performed. Tumor specimens were snap-frozen and stored at $-70^{\circ} \mathrm{C}$. All experiments were performed in accordance with the institutional guidelines for the welfare of experimental animals.

$R N A$ extraction and reverse transcription $(R T)$. For the detection of LHRH receptors total RNA was extracted from frozen tissues by using the TRIzol reagent (Invitrogen, Karlsruhe, Germany). Frozen tissue sections of $300 \mu \mathrm{g}$ were homogenized in $3 \mathrm{ml}$ TRIzol reagent using an Ultra-Turrax (IKA, Staufen, Germany) and further purified according to the manufacturer's instructions. DNA contaminations were digested with RNAse-free DNAse and afterwards the RNA was purified by using the RNeasy-Mini-Kit (both Qiagen, Hilden, Germany). RNA from cell lines was solely purified with the RNeasy-Mini-Kit. The amount and purity of the RNA was determined spectrophotometrically. RNA $(1 \mu \mathrm{g})$ was reversetranscribed with Superscript-III (Invitrogen, Karlsruhe, Germany) using a mixture of oligo-dT and random primers.

For real-time RT-PCR of the epidermal growth factor receptor (EGFR) and HER3 receptors total RNA from six representative $\mathrm{HCC} 1806$ tumors grown in nude mice (tumors from three animals each of the control and the Cetrorelix treated group) was isolated and treated with DNAse using the NucleoSpin-kit (Macherey-Nagel, Bethlehem, PA, USA) according to the manufacturer's instructions. The yield and the quality of RNA samples were determined spectrophotometrically. RNA $(2 \mu \mathrm{g})$ in a total volume of $40 \mu \mathrm{l}$ was reverse transcribed with the QuantiTect-Reverse-TranscriptionKit (Qiagen, Valencia, CA, USA).

PCR for LHRH-I and LHRH receptor. The primers for the amplification of the LHRH receptor were sense: 5'-ATG GGC TGC TGT GCT GGC CAA C-3'; antisense: 5'-TAA GGT GGA AAG GGC TCA GAC C-3'. For the amplification of LHRH-I the primers were: sense: 5'-GCC TTA GAA TGA AGC CAA TTC AA-3'; antisense: 5'-TCC ACG CAC CAA GTC AGT AGA-3'. The PCR was performed for 35 cycles of $15 \mathrm{sec}$ at $95^{\circ} \mathrm{C}, 10 \mathrm{sec}$ at the annealing temperature of $58^{\circ} \mathrm{C}$ followed by $20 \mathrm{sec}$ at $72^{\circ} \mathrm{C}$. The amplified DNA was electrophoresed on a $1 \%$ agarose gel, stained with ethidium bromide and photographed under UV light.

Real-time PCR for EGFR and HER3 receptors. The primers for the amplification of the EGFR were sense: 5'-TTG GTC CTG GGT ATC GAA AG-3'; antisense: 5'-GAA AGG CAG CCA CCA AAT TA-3'. For the amplification of HER3 the primers were: sense: 5'-ACG AGA GGT GTG AGG TGG TG-3'; antisense: 5'-AGA GCG TGG CTG GAG TTG-3'. The primers for the amplification of the GAPDH were sense: 5'-GCT CTC TGC TCC TCC TGT TC-3'; antisense: 5'-GAC TCC GAC CTT CAC CTT CC-3'. All real-time PCR reactions were performed on the iCycler-iQ ${ }^{\mathrm{TM}}$ Real-Time-PCRDetection-System (Bio-Rad, Hercules, CA, USA). Thermal cycling conditions comprised an initial denaturation step at $95^{\circ} \mathrm{C}$ for $3 \mathrm{~min}$ followed by 35 cycles at $95^{\circ} \mathrm{C}$ for $15 \mathrm{sec}$ and an annealing/polymerisation temperature at $60^{\circ} \mathrm{C}(\mathrm{GAPDH})$ or $57^{\circ} \mathrm{C}$ (EGFR and HER3) for $45 \mathrm{sec}$. All samples were run in triplicate in a volume of $25 \mu 1$ containing $2 \mu 1$ of cDNA. Prior to the experiments the efficiencies for all primers were tested, resulting in the range of $95-105 \%$. Human GAPDH was used as a housekeeping gene. Negative controls were run in each reaction consisting of no-RNA in reverse transcriptase reaction and no-cDNA in PCR reaction. The mathematical method described by Pfaffl (29) was used to evaluate the relative expression ratio for all genes compared with GAPDH, with the efficiencies for each set of primers and the $C_{T}$.

Flow cytometry. For flow cytometric analysis, monolayer cultures grown in cell culture flasks were washed with PBS and covered with $1 \mathrm{ml}$ of hypotonic propidium iodide staining solution containing $0.3 \mu \mathrm{l} / \mathrm{ml}$ Nonidet P-40 as described before (30). A rubber policeman was used to scrape the monolayer and vigorous pipetting was used to isolate the stained nuclei. The nuclear suspension was analyzed by a Coulter-XL flow cytometer using an excitation of $488 \mathrm{~nm}$ for the generation of DNA distribution histograms. List-mode data collected on forward and side scatter and DNA content of 10,000 cells was used for generation of DNA histograms and cell cycle distribution analysis by ModFit Program (Verity Software House, Topsham, ME, USA).

In vitro proliferation assay. For in vitro proliferation assays, 3,000 HCC1806 or HCC1937 cells were seeded in a 96-well microplate with $100 \mu \mathrm{l}$ growth media for $24 \mathrm{~h}$. Eight cultures were tested per concentration and the test was replicated at least three times with equal results. The media were then exchanged with phenol red-free DMEM (Invitrogen, Karlsruhe, Germany) without FBS for another $24 \mathrm{~h}$. The next day, media were exchanged with phenol red-free DMEM supplemented with Cetrorelix at concentrations of $0.010 .1,1$ and $10 \mu \mathrm{M}$ or with DMSO used as solvent for Cetrorelix. Up to $1 \mu \mathrm{M}$ Cetrorelix $0.01 \%$ DMSO was used as a solvent control. DMSO $(0.1 \%)$ was used as the solvent control for $10 \mu \mathrm{M}$ Cetrorelix as this was the final concentration of DMSO, here. Another $72 \mathrm{~h}$ later, an MTT tetrazolium salt assay was performed. The MTT-test measures the reduction of the tetrazolium into insoluble colored formazan crystals by the activity of a dehydrogenase within metabolically active cells. The media were withdrawn and $100 \mu 1$ of a 1:10 mixture of methyl-thiazolyldiphenyl-tetrazolium bromide (MTT; Sigma, Deisenhofen, Germany) (5 mg/ml in PBS, pH 7.4) in phenol red-free DMEM media was added to the cells. The cells were incubated under growth conditions for $4 \mathrm{~h}$ or until visible precipitates had formed. The assay was stopped by the addition of $100 \mu 1$ stop solution (50\% N,N-dimethyl formamide; $10 \%$ SDS). The solubilization of the formazan crystals was performed in the dark overnight. The next day, the intensity of the blue color was quantified in a microplate reader at a wavelength of $560 \mathrm{~nm}$. The measured absorbance is proportionate to the number of viable cells. The experiments were performed in hexaplicates and repeated thrice.

Protein extraction. To detect the expression of LHRH-R in lysates of tumor tissues and cell lines, crude cell extracts 
were prepared in RIPA-buffer (TBS, pH 7.6, $1 \%$ Nonidet P-40, $0.5 \%$ sodium deoxycholate, $0.1 \%$ SDS) with freshly added orthovanadate, $1 \mathrm{mM}$ phenylmethylsulfonylfluoride and $2 \mu \mathrm{g} / \mathrm{ml}$ aprotinin for $40 \mathrm{~min}$ on ice. The extracts were homogenized by several passages through a 21 gauge needle and afterwards centrifuged at $10,000 \mathrm{x} \mathrm{g}$ for $10 \mathrm{~min}$ at $4^{\circ} \mathrm{C}$. The supernatant contained the total cell lysate. The protein concentration was determined using the BCA-protein-assaykit (Promega, Mannheim, Germany).

Western blot analysis. The protein extracts were separated by SDS-PAGE and blotted on nitrocellulose membranes (Bio-Rad, Germany). The blots were incubated overnight with an LHRH-R antibody (GnRHR C-18: sc-8681, Santa Cruz Biotechnology, Inc., Heidelberg, Germany) diluted 1:500 in TBST (TBS, $0.1 \%$ Tween-20) with 5\% non-fat dried milk at $4^{\circ} \mathrm{C}$, followed by an incubation with a horseradish peroxidase (HRP) conjugated donkey anti-goat antibody (1:5,000; Santa Cruz Biotechnology) for $1 \mathrm{~h}$. Each incubation with antibodies was followed by three washing steps in TBST for $10 \mathrm{~min}$ each. The immunoreaction was detected by the Immobilon-Western-chemiluminescent-HRP-substrate (Millipore, Schwalbach, Germany) and autoradiography.

Statistical analysis. The data are expressed as the mean \pm standard error of the mean (SEM). The differences between groups were evaluated by One-way ANOVA followed by Dunnet's test.

\section{Results}

Immunohistochemistry of human TNBC specimens. A total of 17 human TNBC samples obtained from primary tumors were examined by immunohistochemistry. Positive staining for LHRH receptors could be observed in all TNBC specimens (Fig. 1). In two samples, high levels of LHRH receptors were detected, three samples showed only a weak LHRH receptor expression and in the remaining eleven samples the expression of the LHRH receptors was moderate.

Expression of $m R N A$ and protein for the LHRH receptor in human specimens and cell lines of TNBCs. PCR of reverse transcribed mRNA from tumor tissues of patients with TNBC showed that all of the 16 specimens tested expressed mRNA for the LHRH receptor (Fig. 2B). The use of specific primers for the LHRH receptor resulted in the amplification of a 319-bp fragment at the expected size. The protein for the LHRH receptor was detected by Western blotting in all of the six tested samples (Fig. 2A). Only six samples could be analysed after most of the specimens were used in total for mRNA purification. Thus, the antibody directed against the LHRH receptor revealed a band at the expected size of $64 \mathrm{kDa}$. In the human TNBC cell lines HCC1806 and HCC1937 mRNA (Fig. 2B) for the LHRH receptor and the corresponding protein (Fig. 2A) were also detected.

Expression of the mRNA for LHRH in human TNBC tumor samples and cell lines. PCR with primers specific for LHRH of reverse transcribed mRNA resulted in the amplification of fragments with a length of $60 \mathrm{bp}$. Bands of the expected size

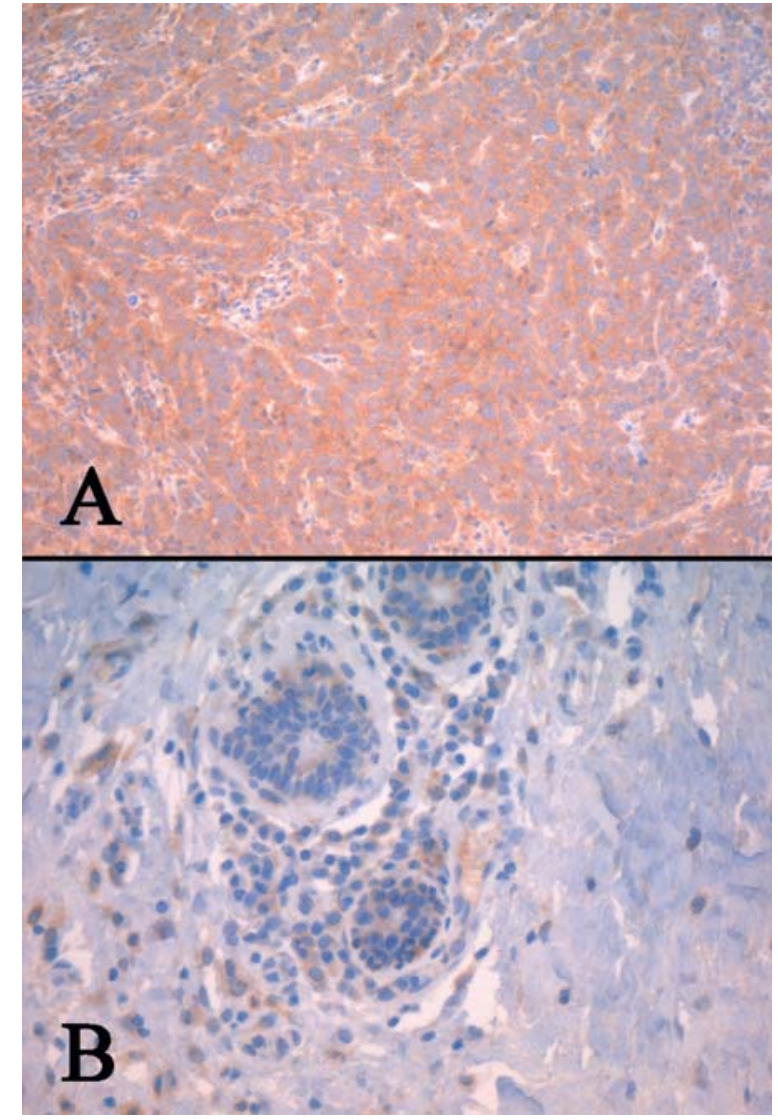

Figure 1. Expression of LHRH receptor in surgically removed human triplenegative breast cancer specimens. The tissues were stained by immunohistochemistry with an antibody against LHRH receptor. (A) TNBC tumor tissue with strong staining of LHRH receptor expressing cells. (B) Benign mammary tissue as negative control. Magnification: A, x100; B, x200.

were detected in both cell lines HCC1806 and HCC1937 as well as in all of the 16 tumor samples of patients with TNBC (Fig. 2C).

Effects of Cetrorelix on the growth of HCC1806 and HCC1937 TNBC cells in vitro. To determine inhibitory effects of the LHRH antagonist Cetrorelix, HCC1806 and HCC1937 were subjected to MTT assay after incubation with Cetrorelix at concentrations of $0.01,0.1,1$ and $10 \mu \mathrm{M}$. The cell proliferation after a period of $72 \mathrm{~h}$ was measured (Fig. 3). At a concentration of $1 \mu \mathrm{M}$ Cetrorelix the growth of the cell line HCC1806 was significantly decreased by $20 \%$ and HCC 1937 by $18 \%$, respectively, as compared to solvent controls using a DMSO concentration of $0.01 \%(\mathrm{P}<0.01)$. At a concentration of $10 \mu \mathrm{M}$ of Cetrorelix the growth of HCC1806 and HCC1937 were significantly inhibited by 12.5 and $35 \%$, respectively, as compared to the solvent controls using a DMSO concentration of $0.1 \%(\mathrm{P}<0.01)$.

Effects of treatment with Cetrorelix on in vivo growth of HCC1806 tumors. For the treatment of TNBC tumors with Cetrorelix in vivo HCC1806 and HCC1937 cells were xenografted into donor mice. While HCC1806 cells produced visible tumors after 2 weeks, HCC1937 did not, even 6 weeks after transplantation. Therefore only the HCC1806 cell line 


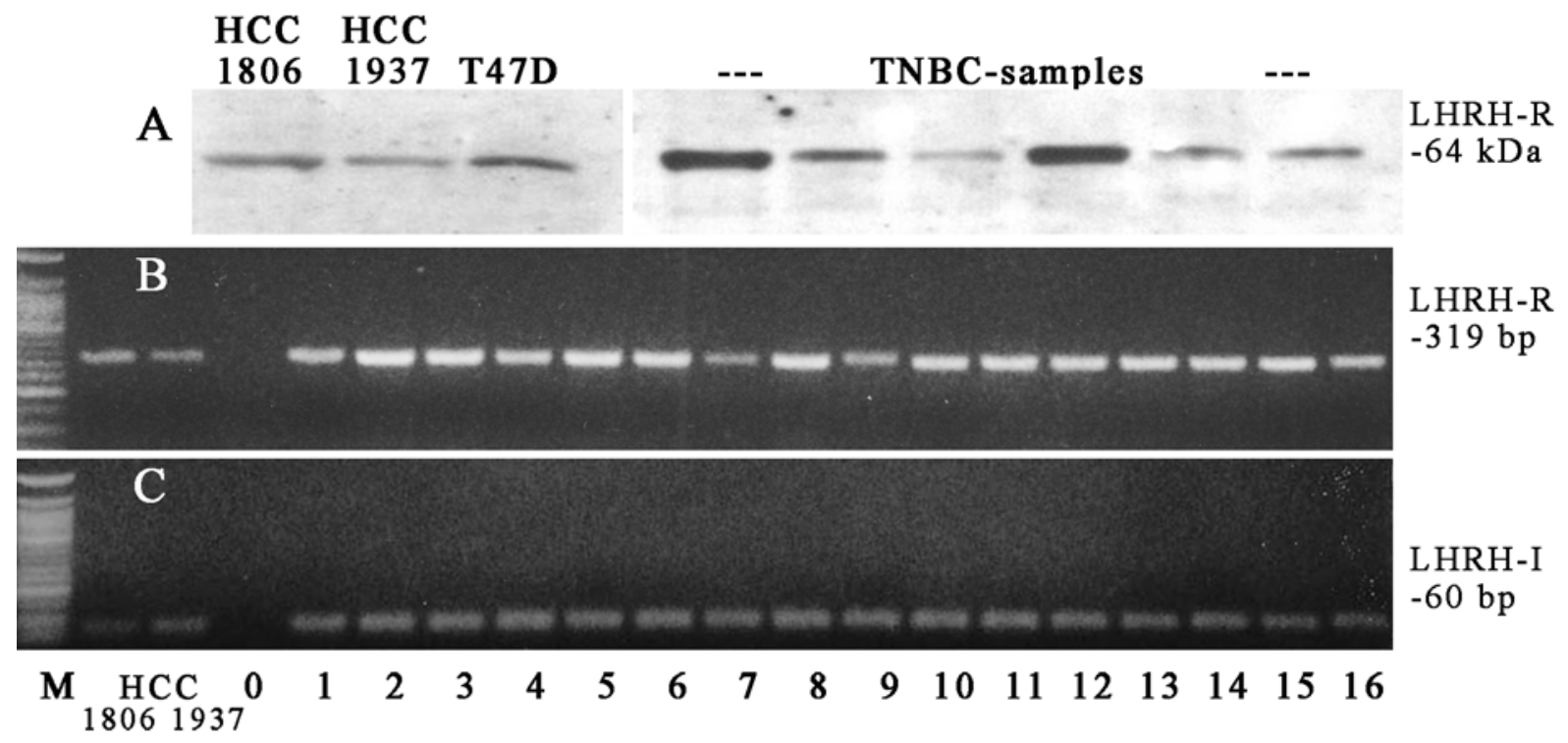

Figure 2. Expression of the LHRH receptor and LHRH-I in TNBC cell lines HCC1806 and HCC1937 and TNBC tumor samples. (A) In the Western blot analysis a band at the expected size of $64 \mathrm{kDa}$ was detected by the antibody against LHRH receptors in both cell lines HCC1806 and HCC1937 and in all of the six tested tumor samples from patients with TNBC. The breast cancer cell line T47D was used as a positive control, showing a band of the equal size. (B) A fragment of $319 \mathrm{bp}$ for the LHRH receptor (LHRH-R), and (C) a fragment of $60 \mathrm{bp}$ for LHRH-I appeared in both cell lines and in all tumor samples . Negative controls for both primer pairs did not produce a PCR product using a mixture of RNA without RT-reaction.
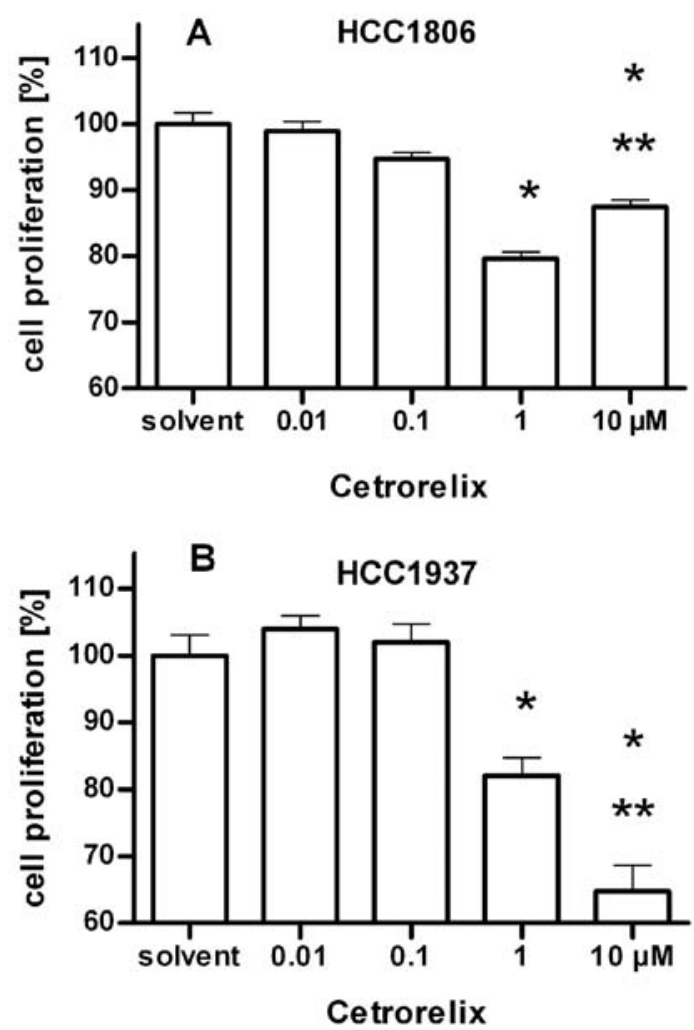

Figure 3. The LHRH antagonist Cetrorelix inhibits the proliferation of the LHRH-R expressing TNBC cell lines: (A) HCC1806; and (B) HCC1937. Cetrorelix $(1 \mu \mathrm{M})$ significantly inhibited the cell growth of both cell lines by $\sim 20 \%$ as compared with the solvent control using media with $0.01 \%$ DMSO Cetrorelix at $10 \mu \mathrm{M}$ concentrations significantly inhibited the growth of: (A) HCC1806, and (B) HCC1937 by 35 and by 13\%, respectively. Cell proliferation was determined in an MTT assay $72 \mathrm{~h}$ after the application of Cetrorelix in the annoted concentrations. ${ }^{*} \mathrm{P}<0.01$, statistically significant difference. ${ }^{* *}$ The application of $10 \mu \mathrm{M}$ Cetrorelix produced a concentration of $0.1 \%$ DMSO in the growth media. Because $0.1 \%$ DMSO itself inhibited the growth of both cell lines, we compared the growth in presence of $10 \mu \mathrm{M}$ Cetrorelix with solvent controls containing $0.1 \%$ DMSO.

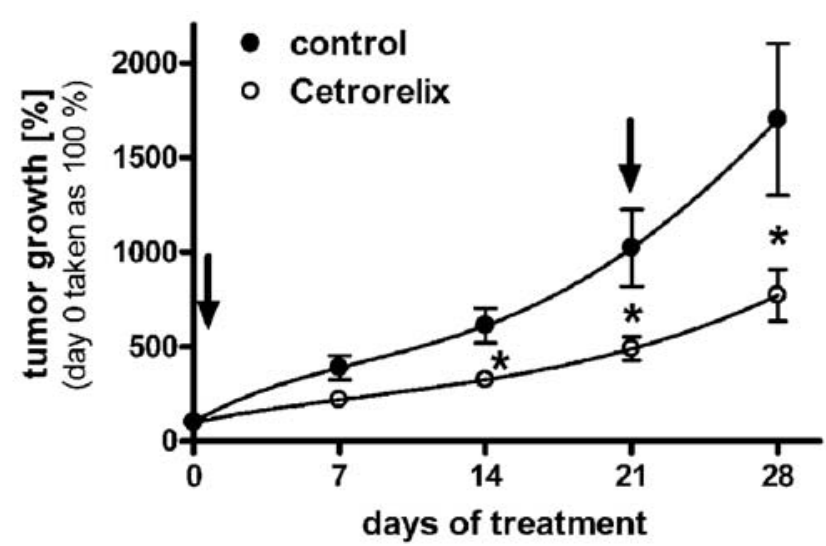

Figure 4. Effect of treatment with LHRH antagonist Cetrorelix on the growth of HCC1806 TNBC tumors xenografted into nude mice. Tumor growth was significantly inhibited in mice treated with Cetrorelix compared to the control group between days 14 and 28 of the experiment. At day 28 the increase of the tumor volume was $53 \%$ less in the treated group. The data in the graph represent the increase of tumor volume, mean \pm SEM. The arrows mark the s.c. injections of $3 \mathrm{mg} / \mathrm{mouse}$ of the Cetrorelix pamoate preparation with an estimated daily dose release of $100 \mu \mathrm{g}$ over 21 days. ${ }^{*} \mathrm{P}<0.05$, statistically significant difference.

was used for the in vivo trial. Two injections of a depot preparation of Cetrorelix pamoate on days 1 and 21, significantly inhibited the growth of tumors derived from the LHRH receptor positive HCC1806 TNBC cell line as reflected by an $53 \%$ inhibition of tumor volume. The inhibition of tumor growth became statistically significant $(\mathrm{P}<0.05)$ as compared with controls on day 14 of the study and remained significant until the end of the experiment on day 28 (Fig. 4).

Expression of mRNA for EGFR and HER3 after Cetrorelix treatment in vitro. In the real-time RT-PCR analysis of tumor tissue derived from the animal trial with the TNBC cell line 
Table I. Reduced expression of mRNA for EGFR and HER3 receptors in xenografted TNBC tumors from mice after treatment with Cetrorelix.

\begin{tabular}{llll}
\hline & \multicolumn{2}{c}{ CT values; mean \pm SEM } & \\
\cline { 2 - 3 } & Control & Cetrorelix & Ratio \\
\hline EGFR & $18.53 \pm 0.11$ & $19.33 \pm 0.05$ & $0.37^{\mathrm{a}}$ \\
HER3 & $22.07 \pm 0.09$ & $22.43 \pm 0.13$ & $0.50^{\mathrm{a}}$ \\
GAPDH & $15.53 \pm 0.12$ & $14.90 \pm 0.21$ & - \\
\hline
\end{tabular}

${ }^{\mathrm{a}} \mathrm{p}<0.05$

Table II. Cell cycle phase analysis performed by the ModFit software in the TNBC cell line HCC1806 after treatment with Cetrorelix.

\begin{tabular}{lccr}
\hline $\begin{array}{l}\text { Cetrorelix } \\
\text { Treatment }\end{array}$ & \multicolumn{3}{c}{ Cells in cell cycle phase (\%) } \\
& G0/G1 & S-phase & G2/M \\
\hline Control & 35 & 58 & 6 \\
$6 \mathrm{~h}$ & 43 & 45 & 13 \\
$18 \mathrm{~h}$ & 42 & 46 & 12 \\
$24 \mathrm{~h}$ & 38 & 52 & 11 \\
\hline
\end{tabular}

aPercentage of cells with the DNA-content of G0/G1, S-phase or G2/M after 6-, 18- and 24-h exposure to $10 \mu \mathrm{M}$ Cetrorelix.

HCC1806 we found a decreased expression of mRNA for EGFR and HER3 receptors in the group with Cetrorelix treated mice compared to the control group (Table I). After treatment with Cetrorelix EGFR expression was decreased to $37 \%$ and HER3 receptor expression by $50 \%$, respectively. Six tumors of each group from treated and untreated mice were investigated after necropsy at day 28 of the experiment. The $\mathrm{C}_{\mathrm{t}}$-values from Real-time RT-PCR for the receptor mRNAs are normalized by using the Ct-values of GAPDH mRNA.

DNA cell cycle analysis by fluorescence-activated cell sorting (FACS). In order to assess if cell growth is arrested by Cetrorelix in a specific phase of the cell cycle, we performed a flow cytometric DNA cell cycle analysis on LHRH receptor expressing HCC1806 TNBC cells exposed to Cetrorelix. This revealed a decrease of cells in the $\mathrm{S}$-phase of the cell cycle as shown by cell cycle phase analysis performed by the ModFit software (Table II). Exposure of cells to Cetrorelix caused a decrease in the number of cells with S-phase DNA content from $58 \%$ in the control to $45 \%$ in cultures treated with Cetrorelix for $6 \mathrm{~h}$. This was accompanied by an increase in the percentage of cells with the DNA content of G0/G1 and $\mathrm{G} 2 / \mathrm{M}$ from 35 and $6 \%$ to 43 and $13 \%$ respectively. This change in cell cycle distribution was evident also in cultures incubated for $18 \mathrm{~h}$. A partial recovery was seen after $24 \mathrm{~h}$.

\section{Discussion}

The present study shows that in the subgroup of TNBCs all tested specimens were stained positive for the LHRH receptor at least with a weak immunohistochemical signal. This finding was confirmed by RT-PCR and Western blot analyses where all of the tested samples were also positive. To investigate the clinical relevance of our results we determined the expression of LHRH receptors also in two human TNBC cell lines by RT-PCR and Western blot analysis. HCC1806 and HCC1937 cells expressed mRNA for LHRH receptor and the corresponding protein was detected with an antiLHRH-R antibody. Accordingly, proliferation assays showed significant, dose-dependent growth inhibition at adequate concentrations of Cetrorelix in HCC1806 and HCC1937 cells. The growth inhibiting effect of Cetrorelix on HCC1806 cells could also be demonstrated in an in vivo-xenograft mouse model. Here, two injections of Cetrorelix carried out on days 1 and 21 significantly decreased tumor growth by $53 \%$. The expressions of the HER3 and EGF receptors were demonstrated in the tumors from HCC1806 TNBC cells xenografted into mice. As shown by Lee-Hoeflich et al (31), HER3 modulates proliferation and differentiation in various human breast cancer cells. Treatment with Cetrorelix led to down-regulation of both HER3 and EGF receptors in tumors of mice treated with Cetrorelix. This down-regulation of receptors suggests a potential mechanism of action by which Cetrorelix induces growth arrest in this tumor subtype. In order to examine the effects of Cetrorelix on the cell cycle distribution of the tumor cells, we performed flow cytometric analyses after treatment with the LHRH antagonist. We observed a decrease of the S-phase fraction of the cells, although we did not find a specific cell cycle arrest. This observation is somehow at variance with previous results by Tang and co-workers (32), as in their work, Cetrorelix led to a cell cycle arrest in G1-phase and induced apoptosis in a dose-dependent manner in LHRH receptor positive HTOA human epithelial ovarian cancer cells. However, these results may be explained by the use of different tumor entities, i.e., ovarian and in our study breast cancer.

Thus, our study provides additional evidence that LHRH acting through its receptor may be involved as a local growth factor in a variety of cancers. Specific receptors for LHRH were detected on human breast, prostatic, ovarian, endometrial and pancreatic cancers (8-16). In an unselected series of human breast cancer samples (containing steroid receptor positive and negative as well as HER2-positive and -negative samples) our group detected high-affinity binding sites for LHRH in $>50 \%$ of the cases. LHRH binding sites were also found in various human breast cancer cell lines, though none of these was of the TNBC subtype $(22,23,26,33)$. The evidence for the production of an LHRH-like peptide and/or the expression of mRNA for LHRH was also demonstrated in human breast, prostatic, ovarian and endometrial cancer cell lines $(8,14,18)$. These findings suggest that locally produced LHRH may be involved in the growth of these tumors, forming an autocrine regulatory loop. This concept is supported by an 
inhibitory action of LHRH agonists and antagonists on human mammary, prostatic, ovarian and endometrial cancer cell lines and exerted through specific LHRH receptors on tumor cells. These actions were demonstrated in vitro, under conditions which exclude effects through the pituitary and gonads $(14,15,18,20,27)$. One clinical phase II study has been performed using the LHRH antagonist Cetrorelix at daily doses of $10 \mathrm{mg}$ to treat 18 patients with advanced platinum resistant ovarian cancer (34). In this heavily pretreated patient group, partial remission, which lasted 9, 16 and 17 weeks, was observed in three patients (18\%), and six patients (35\%) had stable disease.

Currently, the LHRH antagonist Cetrorelix is FDAapproved for the prevention of premature LH surges in ovarian stimulation cycles. Thus, Cetrorelix is used as a routine treatment in the field of reproductive medicine (35). Other potential indications for Cetrorelix, such as the treatment of sex steroid dependent benign diseases i.e., endometriosis or uterine leiomyoma are being investigated in clinical studies (36). Cetrorelix was also demonstrated to produce a clear improvement in the International Prostate Symptom Score (IPSS) in patients with benign prostatic hyperplasia (BPH) and is currently undergoing clinical phase III trials in the USA.

In conclusion, our study demonstrates that specimens of human TNBC express LHRH receptors. We also show that the LHRH receptors mediate proliferative effects in this tumor entity and can be targeted with the LHRH antagonist Cetrorelix. A clear anti-tumor activity of Cetrorelix was demonstrated in an in vivo model of TNBC. The excellent tolerance and the lack of toxicity shown in numerous clinical trials (36), make Cetrorelix a good candidate for phase II studies in patients with advanced TNBC.

\section{Acknoledgements}

This study was supported by Medical Research Service of the Veterans Affairs Department and Aeterna Zentaris $\mathrm{GmbH}$ through South Florida VA Foundation for Research and Education and University of Miami Miller School of Medicine, Department of Pathology (all to A.V. Schally).

\section{References}

1. Carey LA, Dees EC, Sawyer L, Gatti L, Moore DT, Collichio F, Ollila DW, Sartor CI, Graham ML and Perou CM: The triple negative paradox: primary tumor chemosensitivity of breast cancer subtypes. Clin Cancer Res 13: 2329-2334, 2007.

2. Dent R, Trudeau M, Pritchard KI, Hanna WM, Kahn HK, Sawka CA, Lickley LA, Rawlinson E, Sun P and Narod SA: Triple-negative breast cancer: clinical features and patterns of recurrence. Clin Cancer Res 13: 4429-4434, 2007.

3. Bauer KR, Brown M, Cress RD, Parise CA and Caggiano V: Descriptive analysis of estrogen receptor (ER)-negative, progesterone receptor (PR)-negative, and HER2-negative invasive breast cancer, the so-called triple-negative phenotype: a population-based study from the California cancer Registry. Cancer 109: 1721-1728, 2007.

4. Morris GJ, Naidu S, Topham AK, Guiles F, Xu Y, McCue P Schwartz GF, Park PK, Rosenberg AL, Brill K and Mitchell EP: Differences in breast carcinoma characteristics in newly diagnosed African-American and Caucasian patients: a single-institution compilation compared with the National Cancer Institute's Surveillance, Epidemiology, and End Results database. Cancer 110: 876-884, 2007.
5. Rakha EA, El-Sayed ME, Green AR, Lee AH, Robertson JF and Ellis IO: Prognostic markers in triple-negative breast cancer. Cancer 109: 25-32, 2007.

6. Haffty BG, Yang Q, Reiss M, Kearney T, Higgins SA, Weidhaas J, Harris L, Hait W and Toppmeyer D: Locoregional relapse and distant metastasis in conservatively managed triple negative early-stage breast cancer. J Clin Oncol 24: 5652-5657, 2006.

7. Tischkowitz M, Brunet JS, Begin LR, Huntsman DG, Cheang MC, Akslen LA, Nielsen TO and Foulkes WD: Use of immunohistochemical markers can refine prognosis in triple negative breast cancer. BMC Cancer 7: 134, 2007.

8. Emons G, Ortmann O, Becker M, Irmer G, Springer B, Laun R, Holzel F, Schulz KD and Schally AV: High affinity binding and direct antiproliferative effects of LHRH analogues in human ovarian cancer cell lines. Cancer Res 53: 5439-5446, 1993.

9. Emons G and Schally AV: The use of luteinizing hormone releasing hormone agonists and antagonists in gynaecological cancers. Hum Reprod 9: 1364-1379, 1994.

10. Emons G, Schroder B, Ortmann O, Westphalen S, Schulz KD and Schally AV: High affinity binding and direct antiproliferative effects of luteinizing hormone-releasing hormone analogs in human endometrial cancer cell lines. J Clin Endocrinol Metab 77: 1458-1464, 1993

11. Bajusz S, Csernus VJ, Janaky T, Bokser L, Fekete M and Schally AV: New antagonists of LHRH. II. Inhibition and potentiation of LHRH by closely related analogues. Int J Pept Protein Res 32: 425-435, 1988.

12. Szepeshazi K, Schally AV and Halmos G: LH-RH receptors in human colorectal cancers: unexpected molecular targets for experimental therapy. Int J Oncol 30: 1485-1492, 2007.

13. Halmos G, Schally AV and Kahan Z: Down-regulation and change in subcellular distribution of receptors for luteinizing hormone-releasing hormone in OV-1063 human epithelial ovarian cancers during therapy with LH-RH antagonist Cetrorelix. Int J Oncol 17: 367-373, 2000.

14. Limonta P, Pratesi G, Moretti RM, Montagnani Marelli M, Motta $\mathrm{M}$ and Dondi D: Comments on inhibition of growth of androgen-independent DU-145 prostate cancer in vivo by luteinising hormone-releasing hormone antagonist Cetrorelix and bombesin antagonists RC-3940-II and RC-3950-II, Jungwirth et al, Eur J Cancer 1997, 33(7), 1141-1148. Eur J Cancer 34: 1134-1136, 1998.

15. Schally AV and Comaru-Schally AM: Hypothalamic and other peptide hormones. In: Cancer Medicine. Vol. 52(14). 5th edition. Kufe DW, Pollock RE, Weichselbaum RR, Bast RC Jr, Gansler TS, Holland JF and Frei E (eds.) BC Dekker Publishers, Hamilton, pp802-816, 2006.

16. Wormald PJ, Eidne KA and Millar RP: Gonadotropin-releasing hormone receptors in human pituitary: ligand structural requirements, molecular size, and cationic effects. J Clin Endocrinol Metab 61: 1190-1194, 1985.

17. Engel JB and Schally AV: Drug insight: clinical use of agonists and antagonists of luteinizing-hormone-releasing hormone. Nat Clin Pract Endocrinol Metab 3: 157-167, 2007.

18. Schally AV: Luteinizing hormone-releasing hormone analogs: their impact on the control of tumorigenesis. Peptides 20: 1247-1262, 1999.

19. Dondi D, Festuccia C, Piccolella M, Bologna M and Motta M: GnRH agonists and antagonists decrease the metastatic progression of human prostate cancer cell lines by inhibiting the plasminogen activator system. Oncol Rep 15: 393-400, 2006.

20. Emons G and Schulz KD: Primary and salvage therapy with LH-RH analogues in ovarian cancer. Recent Results Cancer Res 153: 83-94, 2000.

21. Sharoni Y, Bosin E, Miinster A, Levy J and Schally AV: Inhibition of growth of human mammary tumor cells by potent antagonists of luteinizing hormone-releasing hormone. Proc Natl Acad Sci USA 86: 1648-1651, 1989.

22. Kahan Z, Nagy A, Schally AV, Halmos G, Arencibia JM and Groot K: Administration of a targeted cytotoxic analog of luteinizing hormone-releasing hormone inhibits growth of estrogen-independent MDA-MB-231 human breast cancers in nude mice. Breast Cancer Res Treat 59: 255-262, 2000.

23. Yano T, Korkut E, Pinski J, Szepeshazi K, Milovanovic S, Groot K, Clarke R, Comaru-Schally AM and Schally AV: Inhibition of growth of MCF-7 MIII human breast carcinoma in nude mice by treatment with agonists or antagonists of LH-RH. Breast Cancer Res Treat 21: 35-45, 1992. 
24. Hershkovitz E, Marbach M, Bosin E, Levy J, Roberts CT Jr, LeRoith D, Schally AV and Sharoni Y: Luteinizing hormonereleasing hormone antagonists interfere with autocrine and paracrine growth stimulation of MCF-7 mammary cancer cells by insulin-like growth factors. J Clin Endocrinol Metab 77: 963-968, 1993.

25. Segal-Abramson T, Kitroser H, Levy J, Schally AV and Sharoni Y: Direct effects of luteinizing hormone-releasing hormone agonists and antagonists on MCF-7 mammary cancer cells. Proc Natl Acad Sci USA 89: 2336-2339, 1992.

26. Bajo AM, Schally AV, Halmos G and Nagy A: Targeted doxorubicin-containing luteinizing hormone-releasing hormone analogue AN-152 inhibits the growth of doxorubicinresistant MX-1 human breast cancers. Clin Cancer Res 9: 3742-3748, 2003.

27. Eidne KA, Flanagan CA, Harris NS and Millar RP: Gonadotropinreleasing hormone $(\mathrm{GnRH})$-binding sites in human breast cancer cell lines and inhibitory effects of GnRH antagonists. J Clin Endocrinol Metab 64: 425-432, 1987.

28. Pinski J, Yano T, Miller G and Schally AV: Blockade of the LH response induced by the agonist D-Trp-6-LHRH in rats by a highly potent LH-RH antagonist SB-75. Prostate 20: 213-224, 1992.

29. Pfaffl MW: A new mathematical model for relative quantification in real-time RT-PCR. Nucleic Acids Res 29: e45, 2001.

30. Krishan A: Rapid flow cytofluorometric analysis of mammalian cell cycle by propidium iodide staining. J Cell Biol 66: 188-193, 1975.
31. Lee-Hoeflich ST, Crocker L, Yao E, Pham T, Munroe X, Hoeflich KP, Sliwkowski MX and Stern HM: A central role for HER3 in HER2-amplified breast cancer: implications for targeted therapy. Cancer Res 68: 5878-5887, 2008.

32. Tang X, Yano T, Osuga Y, Matsumi H, Yano N, Xu J, Wada O, Koga K, Kugu K, Tsutsumi O, Schally AV and Taketani Y: Cellular mechanisms of growth inhibition of human epithelial ovarian cancer cell line by LH-releasing hormone antagonist Cetrorelix. J Clin Endocrinol Metab 87: 3721-3727, 2002.

33. Fekete M, Wittliff JL and Schally AV: Characteristics and distribution of receptors for [D-TRP6]-luteinizing hormonereleasing hormone, somatostatin, epidermal growth factor, and sex steroids in 500 biopsy samples of human breast cancer. J Clin Lab Anal 3: 137-147, 1989.

34. Verschraegen CF, Westphalen S, Hu W, Loyer E, Kudelka A, Volker P, Kavanagh J, Steger M, Schulz KD and Emons G: Phase II study of cetrorelix, a luteinizing hormone-releasing hormone antagonist in patients with platinum-resistant ovarian cancer. Gynecol Oncol 90: 552-559, 2003.

35. Engel JB, Griesinger G, Schultze-Mosgau A, Felberbaum R and Diedrich K: GnRH agonists and antagonists in assisted reproduction: pregnancy rate. Reprod Biomed Online 13: 84-87, 2006.

36. Engel JB, Audebert A, Frydman R, Zivny J and Diedrich K: Presurgical short term treatment of uterine fibroids with different doses of cetrorelix acetate: a double-blind, placebo-controlled multicenter study. Eur J Obstet Gynecol Reprod Biol 134: 225-232, 2007. 